\title{
Analisis Model Pembelajaran Konstruktivisme Terhadap Hasil Belajar Pada Pembelajaran Fisika
}

\author{
Suci Rizki Lestari, Nana \\ Program Studi Pendidikan Fisika, Universitas Siliwangi \\ sucirizkilestari@gmail.com
}

\begin{abstract}
Abstrak
Tujuan penulisan ini adalah untuk mendeskripsikan model pembelajaran konstruktivisme serta untuk mengkaji pengaruh model pembelajaran konstruktivisme terhadap hasil belajar pada pembelajaran fisika dari penelitian sebelumnya. Penelitian ini dilakukan dengan menggunakan metode studi pustaka, yaitu mengkaji berbagai literatur yang kemudian disajikan dalam hasil dan pembahasan sehingga dapat diambil kesimpulan. Berdasarkan hasil analisis dari berbagai sumber literatur, dapat disimpulkan bahwa model pembelajaran konstruktivisme dapat meningkatkan hasil belajar siswa. Model pembelajaran konstruktivisme sangat relevan dengan pembelajaran fisika. Pembelajaran dengan menggunakan model konstruktivisme, dapat membuat siswa membangun sendiri pengetahuan, menemukan langkah-langkah dalam mencari penyelesaian dari suatu materi pelajaran yang harus dikuasai siswa, baik individu maupun kelompok.
\end{abstract}

Keywords: Hasil Belajar, Konstruktivisme, Pembelajaran Fisika

\section{PENDAHULUAN}

Pendidikan adalah salah satu usaha yang dapat dilakukan dalam menyiapkan siswa untuk menghadapi masa yang akan datang. Dengan pendidikan juga berperan dalam mencerdaskan kehidupan bangsa. Sehingga dengan pendidikan dapat menyiapkan Sumber Daya Manusia (SDM) yang baik dalam menghadapi tantangan di masa yang akan datang.

Saat ini kita sedang menghadapi era revolusi 4.0. Pada era ini kita dituntut untuk memiliki kompetensi,menguasai ilmu pengetahuan dan teknologi (IPTEK). Era revolusi industri 4.0 juga berdampak pada peran pendidikan khususnya peran pendidiknya. Jika peran pendidik masih mempertahankan metode konvensional yaitu sebagai penyampai pengetahuan, maka mereka akan kehilangan peran seiring dengan perkembangan teknologi dan perubahan metode pembelajarannya. Kondisi tersebut harus diatasi dengan menambah kompetensi pendidik yang mendukung pengetahuan untuk eksplorasi dan penciptaan melalui pembelajaran mandiri (Nana, 2021).

Kurikulum 2013 merupakan kurikulum yang menggantikan kurikulum yang sudah ada sebelumnya yaitu Kurikulum Tingkat Satuan Pendidikan (Kemendikbud, 2013). Proses pembelajaran dalam kurikulum 2013 dilaksanakan dengan menggunakan pendekatan saintifik dan mencakup tiga ranah yaitu sikap, pengetahuan, dan keterampilan. Hasil akhirnya adalah peningkatan dan keseimbangan antara kemampuan soft skill dan hard skill dari siswa yang meliputi aspek kompetensi sikap, keterampilan dan pengetahuan (Kemendikbud, 2014).

Salah satu bagian dari Ilmu Pengetahuan Alam adalah fisika. Fisika merupakan usaha sistematis dalam rangka membangun dan mengorganisasikan pengetahuan dalam bentuk penjelasanpenjelasan yang dapat di uji dan memprediksi gejala alam (Kemendikbud, 2014). Namun, tidak sedikit siswa di 
sekolah memandang fisika sebagai bidang studi yang sulit, karena harus mempelajari rumus dan konsep-konsep yang abstrak (Astalini et al., 2019). Padahal fisika merupakan sarana berpikir logis untuk memecahkan masalah dalam kehidupan sehari-hari.

Hasil wawancara yang telah dilakukan Azizah menunjukkan adanya permasalahan yang dihadapi oleh guru dalam pembelajaran. Diduga disebabkan oleh penggunaan model pengajaran yang kurang tepat, sehingga menyebabkan siswa tidak menyukai mata pelajaran fisika yang disampaikan oleh guru. Permasalahan ini terlihat dari kurangnya siswa dalam memunculkan pertanyaan, masalah yang penting dan merumuskannya kurang jelas dan tepat. Siswa belum biasa mengumpulkan dan menilai informasi yang relevan serta menggunakan ide-ide abstrak untuk menafsirkannya secara efektif (Azizah et al., 2014).

Berdasarkan data dan informasi yang diperoleh dari hasil observasi Adnyana dan Darmadi bahwa kelas yang memperoleh nilai rata-rata hasil belajar fisika pada tengah semester ganjil tahun 2012/2013 yang masih di bawah standar ketuntasan minimum. Jika dilihat perbandingan persentase ketuntasan siswa di kelas tersebut masih tergolong rendah. Untuk mengatasi kesulitan belajar siswa seorang guru dituntut untuk memiliki kemampuan mengembangkan model pembelajaran yang efektif terutama pada mata pelajaran fisika (Adnyana \& Darmadi, 2012).

Peningkatan hasil belajar yang baik tidak hanya didukung oleh kemauan siswa untuk mau belajar dengan baik, tetapi metode pembelajaran yang digunakan oleh guru juga mempengaruhi hasil belajar siswa. Fakta di lapangan masih ada beberapa guru yang menggunakan model pembelajaran yang kurang menarik bagi siswa sehingga membuat siswa kurang serius dalam mengikuti pembelajaran di kelas. Guru masih mendominasi dalam proses pembelajaran sehingga siswa hanya pasif saja. Trend yang berkembang sekarang ini siswa harus belajar melalui kegiatan mereka sendiri dengan memasukkan konsep-konsep dan prinsip-prinsip, di mana mereka harus di dorong untuk mempunyai pengalaman dan melakukan eksperimen-eksperimen dan membiarkan mereka menemukan prinsip-prinsip bagi mereka sendiri (Kristin, 2016).

Hasil belajar adalah puncak dari keberhasilan belajar siswa terhadap tujuan belajar yang telah ditetapkan. Hasil belajar siswa dapat meliputi aspek kognitif, afektif, dan psikomotorik. Hal ini sesuai dengan pendapat Bettencourt yang menuliskan bahwa, hasil belajar dipengaruhi oleh pengalaman siswa dengan dunia fisik dan lingkungannya $(P$ Suparno, 2012). Hasil belajar seseorang tergantung pada apa yang telah diketahuinya, seperti konsep-konsep, tujuan, dan motivasi yang mempengaruhi interaksi dengan bahan yang dipelajari. Selain itu, model yang digunakan guru ketika proses pembelajaran juga dapat mempengaruhi hasil belajar siswa.

Konstruktivisme merupakan salah satu model pembelajaran yang tidak asing lagi. Dengan model pembelajaran konstruktivisme memberi siswa kesempatan untuk berpikir tentang pengalamannya. Ini dapat mendorong siswa berpikir kreatif, imajinatif, mendorong refleksi tentang model dan teori, mengenalkan gagasan-gagasan pada saat yang tepat (Putri et al., n.d.). Hasil penelitian Ma'arij, menyatakan bahwa model konstruktivisme dapat meningkatkan hasil belajar pada mata pelajaran fisika.

Berdasarkan uraian tersebut, maka fokus penelitian ini yaitu apakah penggunaan model pembelajaran konstruktivisme dapat meningkatkan hasil belajar siswa jika diterapkan di sekolahsekolah yang berbeda tempatnya. 


\section{METODE}

Metode yang digunakan adalah metode studi pustaka, dengan mengkaji berbagai literatur yang kemudian disajikan dalam hasil dan pembahasan sehingga dapat diambil kesimpulan.

\section{HASIL DAN PEMBAHASAN}

Hasil penelitian yang dilakukan adalah:

1. Pengaruh Pendekatan Konstruktivisme Terhadap Hasil Belajar Siswa Pada Konsep Tekanan. Oleh Sutrisni (Sutrisni, 2014).

2. Penerapan Model Pembelajaran Konstruktivisme Berbasis Problem Based Learning (PBL) Untuk Meningkatkan Kemampuan Berpikir Kritis Pada Siswa SMA Negeri 1
Kutowingin Kelas $\mathrm{X}$ Tahun 2013/2014. Oleh Nur Azizah, Siskan Desy Fatmaryanti, Nur Ngazizah (Azizah et al., 2014).

3. Penerapan Model Konstruktivisme Untuk Meningkatkan Hasil Belajar Pada Mata Pelajaran Fisika Pokok Bahasan Usaha dan Energi. Oleh Muh. Fatkhul Ma'arij (Ma'arij, 2016).

Data pada lapora penelitian yang diacu cukupluas dan banyak. Dalam laporan ini, data diolah kembali dengan cara merangkum dan mengambil intisari hasil penelitian saja. Selanjutnya data dilaporkan kembali secara deskriptif kuantitatif dan kualitatif. Hasil ananlisis terkait dengan modelpembelajaran konstruktivisme dapat dilihat pada Tabel 1.

Tabel 1. Hasil Analisis Model Pembelajaran Konstruktivisme

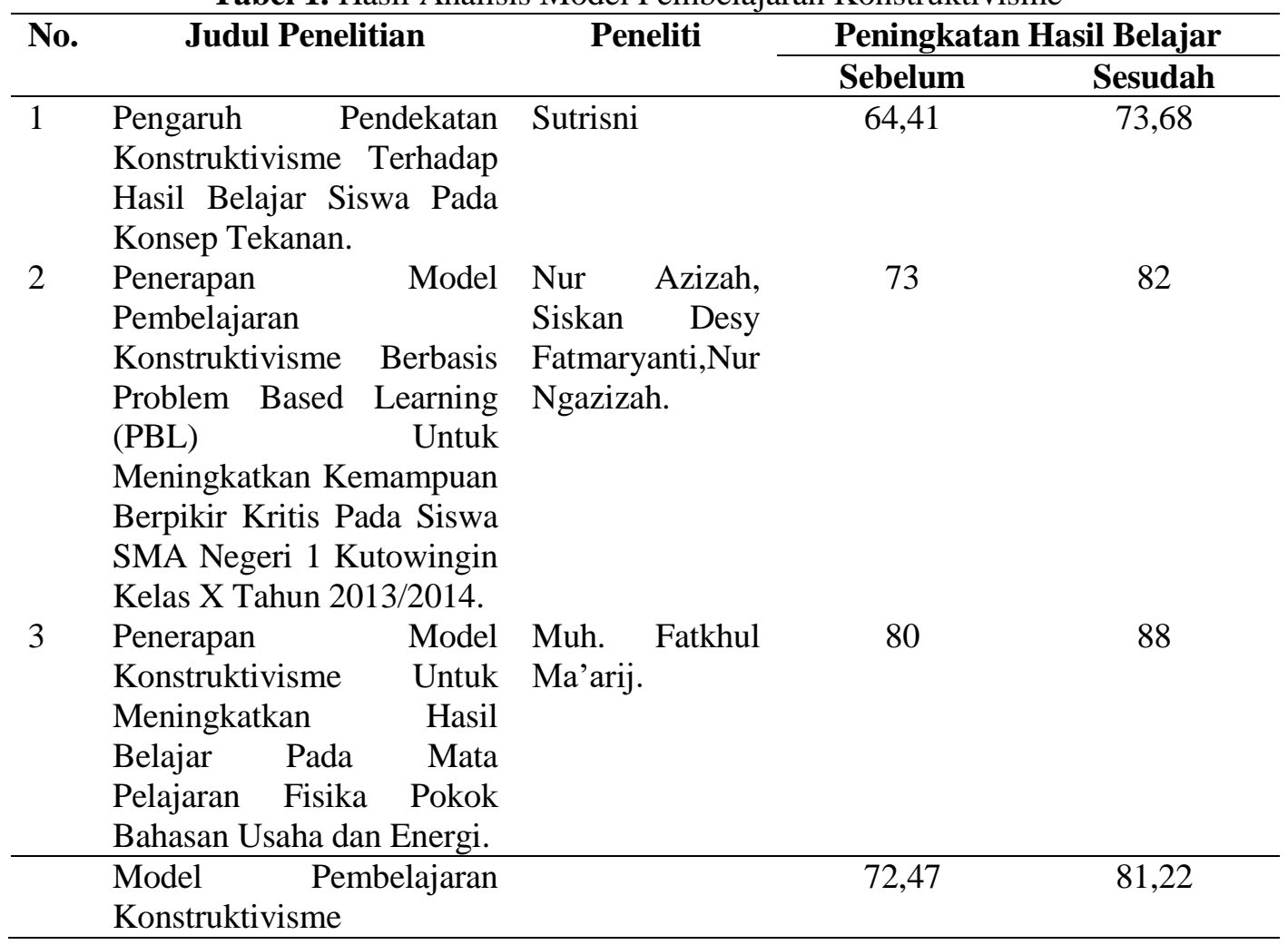

Kondisi dalam proses pembelajaran diatas, setelah diterapkannya model pembelajaran konstruktivisme dalam kelas terjadi perbedaan hasil tes belajar. Perbedaan tersebut disebabkan karena proses pembelajaran dengan model pembelajaran konstruktivisme memiliki tahapan-tahapan pembelajaran yang tidak berfokus pada guru.

$$
\text { Model }
$$$$
\text { pembelajaran }
$$

konstruktivisme memili beberapa tahap. Tahap pertama adalah apserpsi. Pada tahap 
isi siswa di dorong untuk mampu mengemukakan konsep yang akan dibahas. Apabila siswa tidak cukup berani untuk mengemukakan pendapatnya, guru dapat memancing siswa dengan memberikan pertanyaan-pertanyaan permasalahan terkait fenomena yang ditemui siswa dalam kehidupan sehari-hari dengan konsepyang akan di pelajari. Kemudian siswa diberikan kesempatan untuk mengemukakan pemahamnanya terkait konseptersebut. Tahap kedua adalah eksplorasi. Pada tahap ini, siswa diberikesempatan untuk melakukan penyelidikan dalam kegiatan diskusi agar menemukan konsep melalui pengumpulan, pengorganisasian, dan penginterpretasikan data. Tahap ketiga adalah diskusi dan penjelasan kelompok. Pada tahap ini siswa diberikan penjelasan da solusi yang iddasarkan pada hasil observasinya, guru juga harus memberi penguatan terhadap penjelasan yang konsep nya sudah benar. Sehingga siswa dapat membangun pemahaman nya tentang konsep yang sedang dipelajari. Hal ini dapat membuat siswa tidak ragu lagi tentang konsepsinya. Tahap ke empat adalah pengembangan dan aplikasi. Pada tahap ini guru berusaha menciptakan iklim pembelajaran yang memungkinkan siswa supaya mengaplikasikan pemahaman konseptualnya, baik melalui kegiatan atau pemunculan dan pemecahan masalahmasalah yang berkaitan dengan isu-isu di lingkungannya (Lasati, 2007). Sehingga secara keseluruhan model pembelajaran konstruktivisme yang digunakan dapat membuat siswa menjadi lebih aktif dalam menyelesaikan masalah dan menerapkan ilmu fisika dalam kehidupan sehari-hari, sehingga hasil belajar dan kemampuan penemuan siswa secara individu maupun kelompok dapat meningkat (Putri et al., n.d.).

Hal ini sejalan dengan penganut teori konstruktivisme yaitu Von Glasverd yang berpendapat bahwa pengetahuan bukanlah suatu tiruan dari kenyataan. Pengetahuan selalu merupakan akibat dari suatu konstruksi kognitif kenyataan memalui kegiatan yang ada (Paul Suparno, 1997). Maksudnya adalah pengetahuan merupakan ciptaan manusia yang dikonstruksikan dari pengalaman atau dunia sejauh yang dialaminya. Proses pembelajaran ini berjalan terus menerus dengan setiap kali mengadakan reorgansasu karena adanya suatu konsep atau pemahaman baru.

Faktor-faktor yang mempengaruhi hasil belajar adalah faktor-faktor metode pembelajaran, faktor-faktor stimulasi belajar, panjangnya bahan pelajaran, kesulitan bahan pelajaran, berartinya bahan pelajaran, berat-ringannya tugas (Soemanto, 2006). Dengan demikian dalam proses pembelajaran menggunakan model pembelajaran konstruktivisme guru harus dapat memancing siswa untuk berpartisipasi dalam mengemukakan konsep awal dan setelah diskusi.

Penerapan model pembelajaran konstruktivisme dapat meningkatkan hasil belajar dan keaktifan siswa dalam proses pembelajaran, dan guru sebagai fasilitator. Dengan model pembelajaran konstruktivisme memperlihatkan bahwa siswa sangat antusias dalam bekerjasama dengan kelompoknya dan dengan teman teman antar kelompok serta dapat membantu teman yang mengalami kesulitan dalam memahami materi pelajaran tersebut. (Ma'arij, 2016). Hal ini di dukung juga oleh pendapat Ramadhani (Ramadhani, 2012) yang menyatakan bahwa model pembelajaran konstruktivisme dapat meningkatkan hasil belajar siswa.

\section{KESIMPULAN}

Berdasarkan hasil analisis dari berbagai sumber literatur, dapat disimpulkan bahwa model pembelajaran konstruktivisme dapat meningkatkan hasil belajar siswa. Model pembelajaran konstruktivisme sangat relevan dengan pembelajaran fisika. Pembelajaran dengan menggunakan model konstruktivisme, dapat membuat siswa membangun sendiri pengetahuan, menemukan langkah-langkah 
dalam mencari penyelesaian dari suatu materi pelajaran yang harus dikuasai siswa, baik individu maupun kelompok.

\section{REFERENSI}

Adnyana, I. P. W., \& Darmadi, I. W. (2012). Penerapan Pembelajaran Konstruktivisme dengan Siklus Belajar Karplus untuk Meningkatkan Hasil Belajar Fisika Siswa Kelas VIIb 3 SMP Negeri 14 Palu. Jurnal Pendidikan Fisika Tadulako (JPFT), l(2).

Astalini, A., Kurniawan, D. ., Perdana, R., \& Pathoni, H. (2019). Identifikasi sikap peserta didik terhadap mata pelajaran fisika di sekolah menengah atas negeri 5 Kota Jambi. UPEJ Unnes Physics Education Journal, 8 (1), 34-43.

Azizah, N., Fatmaryanti, S. D., Ngazizah, N., \& Kontruktivism, A. (2014). Penerapan Model Pembelajaran Konstruktivisme Berbasis Problem Based Learning ( PBL ) Untuk Meningkatkan Kemampuan Berfikir Kritis Pada Siswa SMA Negeri 1 Kutowinangun Kelas $X$ Tahun Pelajaran 2013 / 2014. 5(2), 24-28.

Kemendikbud. (2014). Pedoman Guru Mata Pelajaran Fisika. Jakarta: Kemendikbud.

Kristin, F. (2016). ANALISIS MODEL PEMBELAJARAN DISCOVERY LEARNING DALAM MENINGKATKAN HASIL BELAJAR SISWA S. Jurnal Pendidikan Dasar PerKhasa, 2(1).

Lasati, D. (2007). Penerapan Pendekatan Konstruktivisme pada Pembelajaran Theorema Phytagoras di Kelas8 SMP. Jurnal Inovatif, 3(1), 47.

Ma'arij, M. F. (2016). PENERAPAN MODEL KONSTRUKTIVISME UNTUK MENINGKATKAN HASIL BELAJAR PADA MATA PELAJARAN FISIKA POKOK BAHASAN USAHA DAN ENERGI. PROSIDING TEMU
ILMIAH NASIONAL GURU (TING) VIII.

Nana. (2021). Inovasi Pembelajaran. Penerbit LAKEISHA: Jawa Tengah.

Putri, N. E., Darmadi, I. W., \& Kunci, K. (n.d.). PENGARUH MODEL PEMBELAJARAN KONSTRUKTIVISME TERHADAP HASIL BELAJAR FISIKA SISWA. Jurnal Pendidikan Fisika Tadulako (JPFT), 2(3).

Ramadhani, N. (2012). Pengaruh Model Pembelajaran Kontruktivis 5E Terhadap Hasil Belajar di SMA Laksamana Martadinata. Jurnal Pendidikan Fisika.

Soemanto, W. (2006). No TitlePsikologi Pendidikan: Landasan Kerja Pemimpin Pendidikan. Jakarta: PT Rineka Cipta.

Suparno, P. (2012). Filsafat Konstruktivisme Dalam Pendidikan.

Suparno, Paul. (1997). Filsafat Konstruktivisme dalam Pendidikan. Yogyakarta: Kamisius.

Sutrisni. (2014). Pengaruh pendekatan konstruktivisme terhadap hasil belajar siswa pada konsep tekanan. UIN SyarifHidayatullah. 